\title{
Evaluasi partisipasi masyarakat pada pembangunan infrastruktur dalam konteks pemberdayaan masyarakat
}

\author{
Fatwa Widodo \\ PT Intan Pariwara. Jalan Ki Hajar Dewantoro No. 1, Karanganom, Klaten, 57411, Indonesia. \\ * Corresponding Author. Email: arifkardi@gmail.com \\ Received: 25 September 2017; Revised: 31 October 2018; Accepted: 3 December 2018
}

\begin{abstract}
Abstrak
Penelitian ini bertujuan untuk mengetahui partisipasi masyarakat pada tahapan perencanaan, implementasi dan hasil dari program pembangunan infrastruktur yang dilakukan oleh Badan Keswadayaan Masyarakat (BKM) Pangudi Mulya. Penelitian ini merupakan penelitian evaluasi dengan pendekatan kualitatif. Model evaluasi yang digunakan ialah CIPP (Context, Input, Prosses dan Product). Teknik pengumpulan data yang digunakan ialah: wawancara, dokumentasi dan observasi sebagai metode penunjang. Teknik analisis data menggunakan reduksi data, display data dan penarikan simpulan. Hasil penelitian menunjukkan bahwa: (1) pada tahap perencanaan warga masyarakat non-anggota ikut berpartisipasi menyuarakan pendapatnya dan ikut serta dalam menyusun rencana program. (2) Pada tahap implementasi, warga non-anggota ikut berpartisipasi dapat dalam bentuk tenaga, materi, donasi maupun logistik. Partisipasi masyarakat dilakukan dengan cara sukarela tanpa adanya paksaan dari anggota BKM. (3) Program pembangunan yang telah dilaksanakan dapat selesai tepat waktu. Hal ini dikarenakan realisasi program dibantu oleh partisipasi masyarakat. Selain itu hasil program dapat merubah keadaan masyarakat, terutama pada sektor kesehatan.
\end{abstract}

Kata Kunci: partisipasi masyarakat pemberdayaan masyarakat, pembangunan infrastruktur.

\section{An evaluation of social participation in infrastructure development for social empowerment context}

\begin{abstract}
The aims of this research were to know social participation in the planning; implementation and product stages of the development program in infrastructure by BKM (Badan Keswadayaan Masyarakat) Pangudi Mulya. This research using CIPP (Context, Input, Prosses and Product) model for evaluate the object. The technique of collecting data were: interview, documentation and observation. The technique of analysis data used: reducting data, display data and conclusion. The results of this research were: (1) in the planning step citizen non member did participation such as idea and include to planned a program. (2) In the implementation step, citizen non member also did participation well. Kinds of participation were had variation, such as: power, material, donated and logistic. Citizen non member did participation without compulsion by BKM member, they did voluntarily. (3) The development program were held on timely. It's because did by participation from citizen. Beside that the result could change social situation, especially on health sector. Keywords: infrastructure development, social empowerment, social participation

How to Cite: Widodo, F. (2018). Evaluasi partisipasi masyarakat pada pembangunan infrastruktur dalam konteks pemberdayaan masyarakat. JPPM (Jurnal Pendidikan dan Pemberdayaan Masyarakat), 5(2), 108121. doi:https://doi.org/10.21831/jppm.v5i2.15932

doi) https://doi.org/10.21831/jppm.v5i2.15932
\end{abstract}




\title{
JPPM (Jurnal Pendidikan dan Pemberdayaan Masyarakat), 5 (2), 2018 - 109
}

\author{
Fatwa Widodo
}

\section{PENDAHULUAN}

Kelurahan Procot berlokasi di Kecamatan Slawi-Kabupaten Tegal. Kecamatan Slawi merupakan ibu kota kabupaten. Meskipun demikian fenomena kemiskinan tetap dapat dijumpai. Oleh karena itu perlu diadakannya program pemberdayaan yang bertujuan untuk mengatasi kemiskinan tersebut.

Dalam rangka mengentaskan kemiskinan, pemerintah bekerja sama dengan masyarakat membentuk suatu Badan Keswadayaan Masyarakat (BKM). BKM dibentuk untuk mengatasi kemiskinan melalui tiga aspek yaitu: kecakpan hidup, sosial dan infrastruktur. BKM yang berada di Kelurahan Procot bernama BKM Pangudi Mulya.

Bagi warga masyarakat diluar anggota BKM memiliki dua peran, yaitu sebagai subjek dan objek. Warga masyarakat sebagai subjek dimaksudkan bahwa BKM mengikutsertakan warga masyarakat non-anggota untuk berpartisipasi aktif dalam pelaksanaan program yang telah direncanakan. Partisipasi disebut Kelompok Swadaya Masyarakat (KSM).

Dalam penelitian ini menggunakan beberapa teori. Pertama ialah teori pemberdayaan. Teori pemberdayaan yang digunakan dalam penelitian ini ialah teori dari Jim Ife. Menurut (Ife \& Tesoriero, 2008) pemberdayaan adalah sebuah proses untuk membantu kelompok atau individu yang kurang beruntung untuk bersaing lebih efektif dengan yang lainnya.

Menurut Sutoro Eko dalam (Andriany, 2015, p. 15) mengatakan bahwa pemberdayaan merupakan proses untuk mengembangkan, proses memandirikan, menswadayakan masyarakat dan memperkuat posisi tawar menawar masyarakat lapisan bawah terhadap kekuatan-kekuatan penekan di segala bidang dan sektor kehidupan.

Sedangkan strategi pemberdayaan salah satunya dapat dilakukan melalui pemberdayaan komunitas. Strategi pemberdayaan komunitas merupakan salah satu proses pembangunan kesadaran yang muncul dari masyarakat untuk memperbaiki keadaan lingkungannya. Realisasi dari munculnya kesadaran tersebut adalah terbentuknya kelompok-kelompok kecil di dalam masyarakat.
Kelompok tersebut berfungsi sebagai pelaksana aspirasi dari masyarakat. Contohnya adalah adanya LSM, BKM, Koperasi, LKMD dan lain-lain (Sutiyono, 2012, p.23)

Dalam perspektif pendidikan nonformal pemberdayaan dilakukan sekaligus memberikan pembelajaran bagi masyarakat. Tujuan pendidikan non-formal ialah: (1) meningkatkan kemampuan kognitif individu melalui pemberian pengetahuan atau wawasan yang bermakna; (2) mengembangkan kualitas diri menuju pencapaian pribadi yang bahagia dan beraktualisasi diri; (3) memelihara masyarakat dari sifat demokratis yang baik serta menumbuhkan individu yang bebas sehingga memungkinkan terwujudnya demokrasi yang sehat. (4) merubah dan/atau mempertahankan tatanan sosial dimana pendidikan menjadi instrumen untuk melakukan transformasi sosial; (5) mencapai keefektifan organisasi dimana pendidikan dinilai sebagai upaya untuk mengembangkan sikap dan keterampilan yang dibutuhkan organisasi dalam pencapaian tujuan secara lebih efektif. (Suryono \& Tohani, 2016, p.2o)

Selain itu, pemberdayaan masyarakat yang dilakukan haruslah bersifat inovatif. Dikatakan bahwa inovasi mengandung tiga aspek; kebermaknaan, kebermanfaatan dan kekomplekkan (Suryono \& Tohani, 2016, p.27).

Teori kedua ialah teori partisipasi masyarakat yang disampaikan oleh Ife \& Tesoriero (2008). Partisipasi merupakan aspek penting dalam pembangunan dan merupakan langkah penumbuh kesadaran. Jadi suatu gerakan pembangunan tanpa adanya kesadaran kontribusi dan kerelaan dari masyarakat akan sulit untuk direalisasikan (Ife \& Tesoriero, 2008).

Dalam penelitian ini parisipasi masyarakat dapat dibentuk melalui strategi komunitas maupun lembaga dalam masyarakat. Strategi komunitas ini cukup efektif. Hal tersebut sesuai dengan hasil penelitian yang menunjukkan bahwa penggunaan strategi komunitas dapat lebih mudah mengelola dan mengorganisir masyarakat terutama dalam berbagai program (Hermawan \& Suryono, 2016, p. 8).

Selain itu pembangunan merupakan suatu proses perubahan sosial yang bertujuan 
untuk mencapai kemajuan sosial secara materil dan imateril melalui partisipasi yang luas dari sautu masyarakat (Asnuddin, 2012, p. 295).

Evaluasi merupakan sebuah proses untuk mengetahui kualitas (nilai dan arti) dari sesuatu berdasarkan pada kriteria-kriteria yang sudah ditentukan. Evaluasi dilakukan secara sistematis dan berkelanjutan. Dimana hasil evaluasi akan menentukan kebijakan/keputusan berikutnya (Stufflebeam, 1994, p. 45).

Sedangkan pendapat lain dikatakan bahwa evaluasi merupakan sebuah langkah untuk memilih, mengumpulkan, menganalisis dan menyimpulkan segala informasi dimana hal tersebut dapat digunakan sebagai dasar penentuan kebijakan maupun perancangan kebijakan/putusan selanjutnya (Weiss, Brennan, Thomas, Kirlik, \& Miller, 2009, p. 166).

Sedangkan guna keperluan evaluasi digunakan model CIPP. Model evaluasi CIPP diciptakan oleh Stufflebeam dan Shinkfield (2012). Model evaluasi CIPP menekankan evaluasi pada empat sektor yaitu: Context, Input, Proses and Product. Proses evaluasi ini dilakukan melalui kolaborasi antara evaluator dan pengambil keputusan.

Evaluasi Context, pada aspek ini evaluasi ditekankan pada level perencanaan. Pada aspek ini evaluasi menekankan pada identifikasi kebutuhan yang kemudian dijadikan landasan penentuan atau pengembangan suatu program.

Evaluasi Input, menyiapkan segala sesuatu yang dinilai akan mempengaruhi pelaksanaan evaluasi. Seperti halnya penentuan sumber yang dibutuhkan, mencari cara alternatif yang dapat dilakukan, penentuan rencana yang matang, menyusun strategi yang akan dilakukan, biaya, peralatan dan perlengkapan.

Evaluasi Process. Pada proses evaluasi ini berkaitan dengan pelaksanaan suatu program. Beberapa pertanyaan harus dijawab dalam proses pelaksanaan evaluasi ini. Pertanyaan-pertanyaan tersebut terkait dengan bagaimana pelaksanaan rencana program, hambatan yang dihadapi dan solusi yang dikeluarkan.
Evaluasi Product. Evaluasi hasil digunakan untuk menentukan keputusan apa yang akan dilakukan berikutnya. Evaluasi hasil berkaitan dengan manfaat dan dampak suatu program setelah dilakukan evaluasi.

Dengan demikian perlu dilakukan sebuah penelitian evaluasi tentang bagaimana BKM Pangudi Mulya dapat memberdayakan masyarakat non-anggota sehingga mereka mau dan mampu berkontribusi serta berpartisipasi pada tiap tahapan program. Tahapan program yang dimaksud ialah mulai dari perencanaan sampai pada pelaksanaan program.

Sedangkan tujuan peneltian ini ialah untuk (1) Untuk mengetahui partisipasi masyarakat pada tahap perencaan dengan mengevaluasi proses perencanaan program pembangunan infrastruktur yang dilakukan oleh BKM Pangudi Mulya. (2) Untuk mengetahui partisipasi masyarakat pada tahap implementasi dengan mengevaluasi proses implementasi program pembangunan infrastruktur yang telah direncanakan oleh BKM Pangudi Mulya. (3) Untuk mengetahui hasil dari program pembangunan infrastruktur yang dilakukan oleh BKM Pangudi Mulya

\section{METODE}

Penelitian ini merupakan penelitian evaluasi dengan pendektaan kualitatif. Penelitian ini dilakukan di Badan Keswadayaan Masyarakat (BKM) Pangudi Mulya yang berlokasi di Kelurahan Procot, kec. Slawi-kab. Tegal. Penelitian ini dilakukan pada bulan Januari sampai Mei 2017.

Subjek pada penelitian merupakan anggota dan sekretaris BKM Pangudi Mulya. Pemilihan subjek dilakukan melalui teknik purposive sampling dan dilanjutkan snowball sampling.

Data penelitian dikumpulkan melalui wawancara (menggunakan metode purposive sampling dilanjutkan dengan snowball sampling, dokumentasi (proposal kegiatan, laporan rapat tahunan dan $\mathrm{AD} / \mathrm{ART}$ ) serta pengamatan di lapangan (observasi).

Analisis yang dilakukan yaitu reduksi data, penyajian data, dan penarikan kesimpulan. Untuk pemeriksaan keabsahan data, peneliti menggunakan triangulasi sumber. 


\section{HASIL DAN PEMBAHASAN}

\section{Hasil}

Partisipasi Warga Masyarakat pada Tahap

Perencanaan

Pada tahap perencanaan partisipasi masyarakat non-anggota sudah dapat dilihat. Hal tersebut dapat diketahui dari pertemuan yang dilakukan oleh anggota BKM Pangudi Mulya dan warga masyarakat non-anggota. Dalam pertemuan tersebut warga masyarakat ikut menyampaikan pendapatnya terkait program yang akan dilakukan. Tak hanya itu, warga masyarakat non-anggota juga ikut menyusun rencana dan menentukan segala kebutuhan guna realisasi program tersebut.

Partisipasi masyarakat non-anggota ini dilakukan pada saat ada pertemuan warga, baik pertemuan RT, RW maupun agenda yang dibuat oleh BKM Pangudi Mulya sendiri. Pertemuan RT/RW disini misalnya arisan atau temu warga rutinan. Sedangkan pertemuan yang diagendakan oleh BKM Pangudi Mulya misalnya agenda rembug warga tahunan.

Warga masyarakat yang ingin berpartisipasi secara intensif kemudian direspon dalam bentuk pembentukkan suatu kelompok swadaya. BKM Pangudi Mulya dalam melibatkan warga non-anggota didasarkan pada beberapa syarat, seperti bersikap baik, jujur, kompetensi, sukarela dan tanpa pamrih. Kelompok ini kemudian disebut sebagai Kelompok Swadaya Masyarakat (KSM). Ruang lingkup KSM ialah menangani per program.

KSM bertugas untuk menentukan alokasi dana, sarana prasarana dan penentuan unit pelaksana. Dikarenakan BKM masih menggunakan dana APBN dan APBD sebagai sumber dana, maka KSM berkewajiban mencari sumber dana lainnya. BKM belum mampu memanfaatkan sumber dana lain seperti dana CSR (Company Social Responsibility) yang telah dialokasikan oleh berbagai perusahaan dan warga kaya sebagai donator.

Parisipasi Masyarakat pada Tahap Implementasi

Tugas utama anggota BKM di lapangan ialah memonitoring, memotivasi serta memberikan sudut pandang alternatif. Pihak yang bertugas penuh dilapangan ialah warga masyarakat non-anggota (KSM). Disinilah keterlibatan atau partisipasi masyarakat nonanggota dapat dilihat dengan nyata.

Untuk penentuan unit pelaksana teknis diambil dari warga masyarakat yang bukan anggota BKM. Pemilihan ini didasarkan pada kriteria khusus seperti: pengelaman kerja, mau bekerja dan tanpa pamrih. Hal ini karena basis kerja BKM ialah sosial bukan komersial. Hal ini juga merupakan bentuk partisipasi masyarakat non-anggota BKM.

Bagi masyarakat yang tidak terdaftar sebagai anggota KSM maupun unit pelaksna teknis bersedia berkontribusi aktif secara sadar dan tanpa arahan spesifik dari BKM. Anggota BKM hanya memberikan pemberitahuan awal akan adanya pelaksanaan program dan mempersilahkan masyarakat untuk ikut berpartisipasi. Sikap untuk bergotong royong masih lekat pada masyarakat.

Bentuk swadaya masyarakat terbagi menjadi tiga macam yaitu: dalam bentuk konsumsi yang ditunjukkan kepada pelaksana teknis (tukang), tenaga pada saat pelaksanaan program dan gagasan atau ide perumusan suatu program.

Secara umum tidak ada kendala dalam rangka mengorganisir masyarakat agar ikut berpartisipasi dalam perencanaan maupun pelaksanaan program. Hal ini disebabkan bahwa apa yang dilakukan adalah untuk masyarakat itu sendiri dan demi mengatasi permasalahan kemiskinan.

Hasil Partisipasi Masyarakat

Semua program yang telah direncanakan dapat diselesaikan dengan tepat waktu. Selain itu tidak terdapat permasalahan seperti: kekurangan dana, kekurangan peralatan maupun perlengakapan, kekurangna logistic, adanya ketidakpuasan dari penerima manfaat, dan lain sebagainya. Semua program yang dilakukan berdasarkan dari kebutuhan masyarakat. Hal tersebut dikarenakan dalam menentukan program BKM Pangudi Mulya juga melibatkan masyarakat non-anggota untuk menentukan program apa yang sesuai.

Adanya perubahan yang terjadi pada warga pasca dilaksanakannya program pembangunan. Perubahan terjadi terutama pada 


\section{JPPM (Jurnal Pendidikan dan Pemberdayaan Masyarakat), 5 (2), 2018 - 112}

Fatwa Widodo

sektor kesehatan. Hal ini terjadi disebabkan oleh pembangunan yang berkaitan dengan sektor kesehatan, seperti: pemasangan jamban, sanitasi, renovasi rumah, dan sebagainya.

Dengan berjalannya waktu diharapkan hasil dari program tersebut dapat berimplikasi pada perubahan sosial pada aspek lain, seperti pendidikan, sosial, politik dan budaya. Dengan demikian program bersifat komprehensif.

\section{Pembahasan}

Partisipasi Warga Masyarakat pada Tahap

Perencanaan

\section{Interpretasi pada Aspek "Konteks"}

Kaitannya dengan analisis konteks, maka pada aspek ini fokus interpretasi berkaitan dengan keterilibatan warga masyarakat non-keanggotaan, penentuan permasalahan, analisis kebutuhan masyarakat, peran warga masyarakat non-anggota dalam merencanakan suatu program serta pertimbangan-pertimbangan yang harus diperhatikan oleh masyarakat dalam menentukan ide suatu program.

Dalam menentukan program yang akan dilaksanakan ada beberapa langkah yang harus diambil oleh anggota BKM Pangudi Mulya. Langkah nyata yang diambil oleh anggota BKM Pangudi Mulya ialah dengan membukan usulan dari warga masyarakat melalui pertemuan RT. Kemudian hasil dari usulan tersebut, anggota BKM memferivikasi usulan dengan datang langsung ke lokasi yang dimaksud. Hasil temuan yang diperoleh di lapangan lalau disampaikan pada pertemuan BKM. Pada pertemuan terebut dikaji mana yang harus dijadikan prioritas. Indikator untuk menentukan prioritas ialah kemanfaatan lingkungan dan masyarakat.

Dua metode tersebutlah yang digunakan oleh BKM Pangudi Mulya untuk menentukan kebutuhan bagi masyarakat Kelurahan Procot. Dimana data tersebut lalu dirumuskan dalam rancangan program pembangunan infrastruktur. Dengan demikian program yang disusun bukanlah program asal ataupun spekulatif berdasarkan khyatalan anggota BKM Pangudi Mulya saja, melainkan keadaan nyata.
Apa yang dilakukan oleh anggota BKM Pangudi Mulya ialah suatu kiat untuk memberdayakan masyarakat non-anggota. BKM Pangudi Mulya ialah suatu lembaga yang berfungsi sebagai motivator warga masyarakat agar ikut andil dan berperan aktif demi kemajuan lingkungannya. Hal ini sesuai dengan tujuan pemberdayaan yang disampaikan oleh K. Suhendra, beliau mengatakan yang intinya bahwa tujuan pemberdayaan salah satunya ialah membentuk masyarakat yang demokratis dan berani mengeluarkan pendapat, memiliki kebebasan merencanakan sesuatu dan memiliki kebebasan untuk memanfaatkan sumber daya lokal (Suminar, Hanim, \& Wahyu, 2016, p. 45).

Berbicara tentang demokrasi, maka proses pemberdayaan yang menumbuhkan sifat demokrasi sangat sesuai dengan perspektif pendidikan non-formal. Folley mengatakan bahwa pendidikan non-formal memelihara masyarakat dari sifat demokratis yang baik serta menumbuhkan individu yang bebas sehingga memungkinkan terwujudnya demokrasi yang sehat. (Suryono \& Tohani, 2016, p. 20).

Dalam pertemuan RT yang dilaksanakan terdapat dialog antara anggota BKM dan warga non-anggota. Terjadi penyampaian pendapat secara sadar dan sukarela tanpa intervensi. Hal ini menandakan adanya rasa bebas/merdeka dalam diri masyarakat. Selain itu, hal ini bisa dikatakan bahwa masyarakat juga memiliki kepedulian dalam kesejahteraan sekitarnya.

Selain melibatkan aspirasi masyarakat, dalam menentukan suatu program pembangunan infrastruktur juga dapat dilakukan berdasarkan usulan anggota BKM Pangudi Mulya sendiri. Hal ini diperbolehkan karena esensinya BKM ialah masyarakat itu sendiri yang terbentuk dalam suatu paguyuban. Berbicara tentang paguyuban atau komunitas, hal ini telah disinggung oleh Hatu. Beliau mengatakan bahwa bentuk realisasi dari adanya kesadaran masyarakat untuk memperbaiki lingkungannya ialah dengan terbentuknya kelompok/ komunitas kecil. Kelompok ini bertugas sebagai pengumpul dan pelaksana aspirasi masyarakat (OwolabiMerus, 2015, p. 76). 


\section{JPPM (Jurnal Pendidikan dan Pemberdayaan Masyarakat), 5 (2), 2018 - 113}

Fatwa Widodo

Bisa dikatakan bahwa BKM Pangudi Mulya sudah melakukan perannya dengan baik sebagai pengumpul dan pelaksana aspirasi masyarakat. Hal tersebut dapat dilihat dari pergerakan anggota BKM Pangudi Mulya untuk mengumpulkan pendapat/ usulan dari masyarakat melalui pertemuan RT.

Pada saat ide program pembangunan infrastruktur telah ditentukan, maka terdapat pertimbangan-pertimbangan tertentu yang harus diperhatikan. Berdasarkan hasil penelitian yang telah dilakukan, poin yang sering menjadi pertimbangan utama ialah kemampuan ekonomi sang calon penerima manfaat. Selain itu, program yang diusung juga diutamakan bersifat individual. Hal ini dilakukan agar dapat langsung dinikmati oleh warga miskin.

Pada penentuan siapa yang akan terlibat dalam pelaksanaan program tidaklah sembarangan. BKM Pangudi Mulya memprioritaskan kepada warga masyarakat nonanggota yang melaksanakan nilai universal dalam kesehariannya. Nilai universal yang dimaksud ialah seperti: jujur, memiliki keahlian, mau bekerja kerjas, bersedia melakukan tugas secara sukarela dan tanpa pamrih. Warga masyarakat yang memenuhi syarat dan mendaftarkan diri lalu diseleksi di dalam rapat BKM. Hasil dari rapat anggota BKM tersebut lalu disosialisasikan kepada masyarakat guna memeroleh persetujuan mufakat.

Berkaitan dengan melibatkan masyarakat non-anggota kedalam pelaksanaan program pembangunan infrastruktur, hal ini sesuai dengan yang diutarakan Sutoro Eko dalam (Andriany, 2015, p. 15). Beliau mengatakan bahwa pemberdayaan sebagai proses pengembangan, memandirikan dan menswadayakan warga masyarakat. Pelibatan masyarakat non-anggota bertujuan untuk membentuk sikap mandiri dikemudian hari. Pada saat anggota masyarakat sudah pernah terlibat dalam pelaksanaan program pembangunan infrastruktur, maka diharapkan masyarakat dapat memecahkan permasalahan yang serupa.

Tatkala suatu sistem memanfaatkan orang dewasa untuk ikut berperan dalam suatu aktivitas, maka hendaknya dimaksudkan untuk mengembangkan kualitas individu dan sosial. Hal ini secara tidak disadari telah dilakukan oleh BKM Pangudi Mulya. Melalui pelibatan masyarakat non-anggota secara tidak langsung telah memberikan pembelajaran kepada mereka untuk menjadi lebih baik (Suryono \& Tohani, 2016, p. 24).

Sumber daya yang ada di masyarakat tidak melulu bersifat alam melainkan juga manusia. Menurut Sumodiningrat (1999) mengatakan bahwa pemberdayaan masyarakat merupakan upaya untuk memandirikan masyarakat melalui perwujudan potensi kemampuan yang mereka miliki. Adapun pemberdayaan masyarakat senantiasa menyangkut dua kelompok yang saling terkait, yaitu masyarakat sebagai pihak yang diberdayakan dan pihak yang menaruh kepedulian sebagi pihak yang memberdayakan.

Dalam hal penentuan lokasi realisasi program, anggota BKM Pangudi Mulya menitikberatkan pada kemanfaatan lingkungan. Artinya program tersebut harus berimplikasi positif terhadap lingkungan sekitar. Selain itu program yang dilaksanakan harus bersifat darurat dan segera dilakukan penanganan. Dengan demikian lokasi yang kiranya masih dapat bertahan akan ditangguhkan terlebih dahulu.

Selain pertimbangan asumtif tersebut, BKM Pangdui Mulya juga memiliki pentunuk teknis. Dalam petunjuk tersebut disebutkan bebarapa hal yang tidak diperbolehkan untuk dilakukan oleh BKM Pangudi Mulya. Dengan adanya pedoman tersebut maka anggota BKM Pangudi Mulya semakin mudah dalam menentukan suatu program. Secara garis besar poin-poin yang dilarang menjadi fokus BKM ialah kegiatan yang akan merusak lingkungan, merusak tatanan kehidupan bermasyarakat dan berbudaya, hal-hal yang bukan menjadi tanggung jawab masyarakat serta bukan kegiatan yang bertujuan untuk mengumpulkan materi semata tanpa melakukan pembangunan atau pembenahan agar lingkungan menjadi lebih baik.

Hal ini sesuai dengan tujuan pembangunan infrastruktur pada aspek lingkungan. Pembangunan infrastruktur harus mampu memanfaatkan sumber daya yang ada secara proporsional dan professional tanpa eksploitasi yang berlebihan. Dengan demikian maka 
kebermanfaatan sumber daya alam dapat dinikmati antar generasi.

Untuk pertanyaan penelitian pertama yang berlaku sebagai analisis konteks dapat disimpulkan bahwa: Pertama, tujuan dari program pembangunan infrastruktur yang dilakukan oleh BKM Pangudi Mulya ialah untuk meningkatkan kesejahteraan masyarakat miskin. Peningkatan kesejahteraan tersebut dapat dilihat dari peningkatan pola hidup sehat melalui ketersediaan fasilitas dasar seperti jamban. Selain itu juga kondisi rumah yang lebih baik karena program renovasi dan pengadaan aliran listrik dapat menjadi indicator perbaikan kualitas hidup masyarakat miskin.

Kedua, dalam menentukan program pembangunan dilakukan dengan dua cara, yaitu: pengamatan langsung oleh anggota BKM dan melibatkan aspirasi masyarakat melalui pertemuan RT maupun RW. Dengan demikian program yang disusun sesuai dengan realita dan kebutuhan masyarakat. Ketiga, adanya pertimbangan-pertimbangan tertentu dalam menentukan objek mana yang harus didahulukan. Pertimbangan tersebut meliputi: kemanfaatan lingkungan, keadaan ekonomi calon penerima dan urgensi objek.

Keempat, penentuan siapa saja yang terlibat dalam perencanaan maupun pelaksanaan dilakukan dengan sangat selektif. Syarat yang harus dipenuhi adalah: ketersediaan untuk bekerja keras dan tanpa pamrih, mengamalkan nilai universal dalam gerak kesehariannya dan memiliki ketrampilan sesuai program. Dengan demikian dapat diartikan bahwa dalam aspek "konteks", program pembangungan infrastruktur yang dilakukan oleh BKM Pangudi Mulya sudah sesuai dengan pedoman maupun kebutuhan

\section{Interpretasi pada Aspek "Masukan"}

Pada tahap perencanaan maupun pelaksanaan program, pelibatan masyarakat non-anggota secara nyata dilihat dengan adanya pembentukkan KSM (Kelompok Swadaya Masyarakat). Tugas dari KSM ialah menyusun rencana dalam bentuk proposal berikut alokasi dana, materi, pelaksna teknis dan sebagainya. Mubyanto mengatakan bahwa dalam proses pemberdayaan, masyarakat diarahkan pada pengembangan sumber daya manusia (Pangesti, 2012, p. 26).

Dengan adanya pelibatan masyarakat dalam bentuk KSM, maka ketrampilan masyarakat mengalami perkembangan terutama dalam aspek orgranisasi. Masyarakat bisa secara mandiri menentukan kebutuhan dan menyelesaikan permasalahan yang ada. Selain itu masyarakat juga mampu menyusun skema, kebutuhan material bahkan pendanaan secara otonom.

Selain itu, pada tahap ini selaras dengan konsep partisipasi oleh Ife \& Tesoriero (2008). Ia mengatakan bahwa partisipasi merupakan aspek penting dalam pembangunan dan merupakan langkah penumbuh kesadaran. Dengan demikian suatu program pembangunan tidak akan mencapai realisasi jika tanpa adanya kesadara kontribusi dan kerelaan dari masyarakatnya. Adanya kesadaran yang dimiliki masyarakat Kelurahan Procot untuk melakukan pembenahan pada lingkungannya menyebabkan program pembangunan dapat dilaukan (Ife \& Tesoriero, 2008).

Pada tahapan penentuan dana, awalnya anggota BKM melakukan pemetaan kebutuhan. Hasil temuan di lapangan kemudian disusun dalam rencana program. Setelah disusun kemudian diajukan kepada pemerintah pusat. Namun pada program lanjutan, besarnya dana sudah ditentukan oleh pemerintah berikut alokasi bidangnya. Dengan demikian BKM Pangudi Mulya hanya menyusun rencanga anggaran belanja sesuai dana yang ada. Dari sinilah pada akhirnya terdapat seleksi atau penentuan prioritas bagi objekobjek yang kiranya harus didahulukan realisasinya.

Untuk pemenuhan sarana dan prasarana yang melingkupi bahan material dan pembiayaan, semua ditentukan oleh KSM yang berkordinasi dengan faskel bidang inrastruktur. Hasil dari kordinasi tersebut adalah proposal kegiatan. Pada tahap ini, anggota BKM Pangudi Mulya hanya berperan sebagai pendamping.

Apa yang dilakukan oleh KSM sebagai representasi masyarakat bersama dengan faskel sesuai dengan konsep yang diutarakan oleh Suharto (2005). Jika dikorelasikan dengan konsep yang diutarakan oleh Edi 
Suharto, apa yang dilakukan oleh KSM termasuk dalam tahap kedua yaitu "Penguatan". Dalam konsep ini, Suharto (2005) mengatakan bahwa pemberdayaan harus mampu meningkatkan penguatan pada pemahaman lokal. Serta kemampuan praktis guna menyelesaikan masalah yang ada di lingkungannya (Razali, 2004, p, 66).

Tidak semua individu dapat mengabstraksikan ide kedalam informasi tertulis seperti proposal kegiatan. Melalui pelibatan masyarakat non-anggota yang dibimbing oleh Faskel, secara tidak langsung telah terjadi pembelajaran terhadap masyarakat. Pembelajaran tersebut ialah bagaimana cara menyampaikan ide dan menyusunnya secara sistematis menjadi sebuah proposal.

Sedangkan langkah yang diambil oleh anggota BKM untuk memberikan pemahaman kepada masyarakat non-anggota tentang program yang diusung ialah melalui sosialisasi. Sosialisasi yang dilakukan pada saat ada pertemuan warga baik dalam ruang lingkup RT maupun RW. Dalam pertemuan tersebut disampaikan berbagai rencana program dari BKM Pangudi Mulya. Sekaligus juga menampung berbagai usulan, kritikan maupun keluhan dari warga masyarakat.

Apa yang dilakukan oleh anggota BKM Pangudi Mulya ini juga sesuai dengan konsep tahapan pemberdayaan menurut Edi Suharto. Tahapan dimana terjadi pemahama terhadap masyarakat disebut tahap "Penyokongan". Pada tahap ini bisa diartikan sebagai langkah memberikan pemahaman kepada masyarakat mengenai peran yang harus dilakukan. Mengapa hal ini harus dilakukan, karena pada tiap masyarakat masing-masing individu memiliki status dan peran masing-masing. Pada tahap "penyokongan", masyarakat diberikan penjelasan yang lebih detail tentang peran yang harus dilakukan sesuai dengan status yang disandangnya.

Meskipun partisipasi dari masyarakat sudah cukup baik. Namun dalam pemanfaatan sumberdaya yang ada, BKM Pangudi Mulya masih mengalami kelemahan. Adanya fakta bahwa anggota BKM Pangudi Mulya tidak mengetahui adanya sumber dana selain dari pemerintah pusat (APBN) dan daerah (APBD). Sumber dana yang dimaksud ialah dana CSR (Corporate Social Responsibility) dari perusahaan-perusahaan sekitar.

Perlu diketahui bahwa Kecamatan Slawi dimana Kelurahan Procot berada, banyak berdiri perusahan-perusahaan yang memilki dana CSR. Perusahaan seperti bank (baik BUMN maupun swasta), showroom motor dan mobil, perusahaan teh (ada lima industri besar yang bergerak dibidang produksi teh), perusahaan obat dan perusahaan maupun industri kecil lainnya.

Kelurahan Procot yang berada di tengah Kecamatan Slawi merupakan lokasi yang strategis untuk memanfaatkan dana CSR tersebut. Namun sampai saat ini, sumber dana tersebut belum juga dimanfaatkan dengan baik. Adanya kesulitan menyusun laporan sponsor maupun ketidak tahuan mekanisme pengajuan dana menjadi distorsi yang harus dihilangkan.

Padahal, menurut Suharto (2005), gerakan pemberdayaan bertujuan untuk memperkuat kekuasaan pada masyarakat (Andriany, 2015, p. 15). Atau pada konsep tahapan pemberdayaan disebut sebagai "Pemungkinan". Pemungkinan/memperkuat kekuasaan tersebut dapat dilakukan melalui rekayasa lingkungan masyarakat. Artinya adalah memanfaatkan segala potensi dan sumber daya yang ada demi kemanfaatan lingkungan dan masyarakat. Jika BKM Pangudi Mulya sebagi lembaga pemrekarsa pemberdayaan di masyarakat, tetapi masih bergantung kepada dana dari pemerintah, bisa dikatakan BKM Pangudi Mulya belum sepenuhnya menjadi pionir pemberdayaan

Seharusnya dana dari pemerintah baik pusat maupun daerah hanya dijadikan stimulan maupun modal awal bagi BKM Pangudi Mulya. Untuk selanjutnya anggota BKM mencoba mencari dan memanfaatkan sumbe dana lain yang ada. Atau mungkin bisa memanfaatkan warga masyarakat yang dinilai kaya atau memiliki harga lebih. Orang-orang seprti ini bisa diberdayakan menjadi donatur aktif.

Namun dalam konteks pengadaan program pembangunan infrasturktur, swadaya konsumsi maupun tenaga tidaklah cukup. Perlu adanya masukan berupa dana maupun material yang dibutuhkan. Item inilah yang sangat menunjang realisasi 
program pembangunan infrastruktur. Tanpa adanya sumber dana yang dapat dimanfaatkan maupun bahan material, maka apapun program pembangunan infrastruktur yang disusun hanya akan bersifat wacana atau angan saja.

Dari uraian tersebut dapat dikatakan bahwa meskipun masyarakat Kelurahan Procot baik anggota BKM maupun KSM tidak begitu paham tentang konsep pemberdayaan secara teori, namun apa yang telah dilakukan sudah sesuai dengan konsep pemberdayaan yang disampaikan oleh para ahli. Untuk pertanyaan penelitian yang berkaitan dengan aspek "masukan" (input) dapat disimpulkan, yiatu: Pertama, sumber daya yang potentif untuk dimanfaatkan dalam rangka pembangunan infrastruktur ialah masyarakat Kelurahan Procot itu sendiri, kedua ialah pemerintah baik pusat maupun daerah sebagai penyedia dana dan ketiga adalah perusahaan sebagai pihak ketiga yang memiliki pontesi sebagi penyedia dana.

Kedua, BKM Pangudi Mulya telah memanfaatkan sumber daya manusia dengan baik. Hal tersebut dapat dilihat dari pelibatan para warga non-keanggotaan kedalam program. Warga tersebut berperan sebagai sumber swadaya dalam bentuk logisitik maupun bantuan tenaga saat pelaksanaan. Perekrutan warga non-anggota dilakukan dengan cara sosialisasi di pertemuan-pertemuan warga.

Ketiga, BKM Pangudi Mulya masih belum memanfaatkan sumber dana pihak ketiga. Dalam konteks ini ialah para perusahaan yang tersebar disekitar Kelurahan Procot. Sampai saat ini BKM Pangudi Mulya hanya menggantungkan diri kepada APBN dan APBD. Dengan demikian BKM Pangudi Mulya belum sepenuhnya menjadi badan yang berdaya dan memberdayakan masyarakat secara utuh dan mandiri

Parisipasi Masyarakat pada Tahap Implementasi

Sikap keterbukaan dan fleksibel yang dimiliki anggota BKM sesuai dengan konsep tahapan pemberdayaan yang dikemukakan oleh Edi Suharto. Tahap dimana adanya sinergitas antara pemberdaya (BKM) yang diberdayakan (KSM) disebut "Pemeliharaan". Dalam konsep "Pemeliharaan" integrasi antar individu maupun kelompok harus dapat dilakukan. Dengan demikian masyarakat memiliki rasa percaya, aman dan nyaman untuk meningkatkan kesejahteraannya.

Dengan adanya kerjasama dan dialog yang hidup antara BKM dan KSM akan mempermudah pelaksanaan program. Dalam konteks ini tidak ada pihak yang "memerintah" dan "diperintah". Semua pihak memiliki peran masing-masing dan saling berkorelasi serta berada pada satu lapisan yang sama. Inti dari pelaksanaan program ialah kerjasama dan komunikasi. Kedua hal tersebut dilakukan dengan baik oleh masyarakat Kelurahan Procot.

Untuk pelaksana teknis atau dalam konteks realisasi program pembangunan infrastruktur disebut "tukang", dipilih berdasarkan beberapa kriteria. Berdasarkan hasil wawancara diketahui bahwa warga masyarakat harus memenuhi kriteria agar dapat menjadi tim pelaksana teknis. Kriteria tersebut seperti: memiliki pengalaman kerja yang cukup, mau bekerja dan tanpa pamrih. Untuk program-program yang melibatkan pihak professional, maka kriterianya pun lebih ketat.

Salah satu contohnya ialah pada program instalasi listrik. Pada program ini tidak semua warga non-anggota dapat melakukannya. Hanya orang-orang yang memiliki sertifikat dan diakui oleh PLN yang dapat melakukan tugas instalasi listrik. Hal ini perlu dilakukan demi efisiensi dan efektifitas realisasi program.

Adanya program pembangunan infrastruktur seperti instalasi listrik, pada faktanya tidak menutup kemungkinan adanya keterlibatan pihak lain. Berdasarkan keterangan dari narasumber, menjelaskan bahwa untuk program instalasi listrik tak jarang melibatkan pihak ketiga. Pihak ketiga ini berupa agen dan sudah memiliki legalitas menjalankan tugas oleh PLN.

Keputusan masyarakat Kelurahan Procot untuk melibatkan orang "asing" atau pihak ketiga guna memenuhi kebutuhannya adalah suatu tindakan yang baik. Karena berdasarkan pendapat Rogers mengenai pembangunan. Beliau mengatakan bahwa pembangunan merupakan suatu kegiatan sosial yang bertujuan untuk merubah suatu 


\section{JPPM (Jurnal Pendidikan dan Pemberdayaan Masyarakat), 5 (2), 2018 - 117}

Fatwa Widodo

keadaan menjadi lebih baik. Dan pada kegiatan tersebut dilakukan melalui partisipasi secara luas dari suatu masyarakat. Artinya bahwa program pembangunan sudah sepantasnya tidak hanya dilakukan oleh satu kelompok atau masyarakat, melainkan kerja sama dengan berbagai pihak yang memiliki kapasitas dan kapabilitas (Asnudin, 2012, p.295).

Keterlibatan pihak luar tidak dapat dihindari. Hal ini sudah merupakan tabiat manusia, yaitu sebagai makhluk sosial. Sebagai makhluk sosial, manusia tidak mampu memenuhi kebutuhannya secara mandiri tanpa bantuan orang lain. Namun bantuan dalam konteks ini ialah bekerjasama bukan menggantungkan diri kepada satu pihak. Menggantungkan diri pada satu pihak menandakan ketidakberdayaan. Sedangkan dalam konteks pembangungan, pemberdayaan sangatlah diperlukan.

Dalam perspektif Talcott Parsons dalam (Ritzer \& Goodman, 2011, p. 121) dikenal istilah "strukturalisme fungsionalis". Artinya di dalam masyarakat hakikatnya terdiri dari berbagai unit yang saling berhubungan dan memiliki fungsi masingmasing. Dengan demikian, suatu masyarkat tidak mampu menjalankan dinamikanya tanpa intervensi pihak lain. Dan teori ini "dipahami" dan dilaksanakan oleh BKM Pangudi Mulya serta KSM.

Meskipun dalam pelaksanaan komunikasi dan kerjasama antar pihak dapat dilakukan dengan baik, namun permasalahan tetap tidak bisa dihindari. Berdasarkan penjelasan yang diberikan oleh narasumber, diketahui bahwa permasalahan justru datang dari calon penerima manfaat dan pelaksana teknis. Permasalahan yang datang dari calon penerima manfaat disebabkan oleh adanya ketidak pahaman atas program yang diusung oleh BKM.

Sedangkan permasalahn dari pihak pelaksana teknis, lebih bersifat individual. Seperti keengganan untuk menikmati sajian yang diberikan oleh pemilik rumah maupun meminum minuman yang diberikan oleh tuan rumah. Hal ini disebabkan oleh adanya persepsi bahwa calon penerima manfaat adalah orang miskin yang identik dengan kumuh serta kotor. Dengan demikian para pelaksna teknis (tukang) merasa risih dan enggan untuk menikmati sajian yang ditawarkan.

Langkah yang diambil oleh anggota BKM yang pertama ialah rapat kordinasi antar anggota. Rapat tersebut dilakukan guna mengetahui duduk permasalahan, ketika sudah diketahui maka dintentukan solusinya. Solusi yang ditawarkan biasanya adalah: apakah perlu melibatkan anggota BKM untuk menyelesaikannya atau cukup KSM dan UPL? Jika anggota BKM diperlukan bantuannya maka dengan kesepakatan salah satu anggota BKM akan turun lapangan. Pada saat di lapangan, anggota BKM akan menghubungi tokoh masyarakat setempat seperti RT ataupun sesepuh untuk ikut andil dalam menyelesaikan masalah dengan pendekatan persuasif.

Menjelaskan pada warga yang belum bisa memahami kedudukan program pembangunan infrastruktur yang dilakukan oleh BKM merupakan sikap yang harus dilakukan. Karena salah satu sifat pembangunan menurut Kleinjans ialah proses perolehan pemahaman oleh warga masyarakat. Jika masih terdapat warga masyarakat yang belum memahami tentang kedudukannya dalam konteks program maupun kedudukan program itu sendiri, hal tersebut akan menjadi hambatan realisasi program.

Semua warga masyarakat hendaknya memahami tujuan, maksud dan aturan yang berkenaan dengan suatu program. Karena menurut Kleinjans dengan adanya pemahaman dari warga masyarakat maka akan muncul kesadaran dan kepedulian. Dengan demikian proses realisasi program pembangunan dapat dilakukan dengan lancar.

Sedangkan langkah yang diambil oleh anggota BKM Pangudi Mulya ketika terjadi ketidak sesuaian antara realisasi progam dan rencana adalah melakukan rapat kordinasi. Rapat kordinasi tersebut diikuti oleh anggota BKM dan pihak pelaksana teknis/tukang. Dengan demikian bisa diketahui akar permasalahannya dan solusi yang tepat untuk menanganinya.

Dengan adanya kontribusi dari masyarakat diharapkan terbentuknya sikap mandiri dari masyarakat. Warga masyarakat harus peka terhadap lingkugan, mampu memecah- 
kan masalah yang ada dan mampu memenuhi kebutuhannya secara mandiri tanpa bergantung dengan pihak lain. Selain itu dengan adanya program pembangungan infrastruktur diharapkan adanya perubahan pola hidup pada masyarakat miskin. Pola hidup yang dimaksud ialah pola hidup yang lebih sehat setelah adanya jamban, misalnya.

Dengan demikian keberadaan lingkungan kumuh dapat dikurangi. Serta adanya pemerataan kepemilikan fasilitas pribadi yang bersifat dasar. Hal tersebut dilakukan karena tujuan umum dari adanya program pembangunan infrastruktur ialah mengatasi permasalahan kemiskinan.

Simpulan dari pertanyaan penelitian dalam konteks "pelaksanaan" ini ialah: Pertama, masing-masing pihak seperti anggota BKM, KSM, pelaksana teknis dan warga nonanggota melakukan peran sesuai dengan statusnya. Kedua, kendala yang dihadapi pada saat pelaksanaan diselesaikan melalui pendekatan persuasive dan melibatkan tokoh masyarakat sebagai penguat argument. Ketiga, ketika proses pelaksanaan tidak sesuai dengan apa yang telah direncanakan maka dilakukan rapat kordinasi. Rapat kordinasi ini melibatkan anggota BKM setempat (dimana lokasi realisasi program berada), KSM terkait (selaku panitia pelaksna) dan pelaksana teknis/tukang.

Keempat, harapan BKM Pangudi Mulya setelah adanya realisasi program ialah perubahan sikap dari masyarakat. Sikap yang dimaksud ialah sikap peka terhadap lingkungan dan peduli terhadap sesame. Selain itu juga dengan adanya program pembangunan infrastruktur diharapkan ada perubahan pola hidup masyarakat. Pola hidup yang di maksud ialah pola hidup yang lebih sehat. Dengan demikian permasalahan kemiskinan dari segi infrastruktur kiranya dapat dikurangi keberadaanya

\section{Hasil Program Pembangunan Infrastruktur}

Terkait dengan hasil yang telah dicapai berdasarkan keterangan narasumber sudah sesuai dengan kebutuhan masyarakat. Hal ini disebabkan karena munculnya program didasarkan bada usulan warga masyarakat. Selain itu juga didasarkan pada pengamatan langsung oleh anggota BKM. Dengan demikian kemungkinan ketidak-efektifan dari program dapat diminimalisir.

Apa yang dilakukan oleh anggota BKM Pangudi Mulya sudah sesuai dengan yang dikatakan oleh Stark dan Thomas. Kedua pakar tersebut mengatakan bahwa data yang diperoleh melalui: memilih, mengumpulkan, menganalisis dan menyimpulkan segala infrormasi dapat digunakan sebagai dasar penentuan kebijakan maupun perencanaan kebijakan selanjutnya (Weiss, et.al., 2009, p. 166).

Demi efektifitas hasil program, anggota BKM melakukan dua metode. Metode pertama ialah membangun dialog dengan warga masyarakat non-anggota. Dalam dialog tersebut diperoleh usulan maupun ide program yang dapat dilakukan. Metode kedua ialah berdasarkan pengamatan pribadi anggota BKM sendiri. Dengan demikian ide program berangkat dari unsure kebutuhan dan realita dilapangan.

Sedangkan pada tahap perencanaan atau penyusunan progam maupun pelaksanaan program, anggota BKM melibatkan semua lapisan masyarakat. Hal tersebut dilakukan agar proses pemberdayaan dapat berlangsung secara merata. Dengan demikian harapan untuk menjadi masyarakat yang mandiri dan peka lingkungan dapat segera terlaksana. Dari uraian tersebut dapat ditarik garis merah bahwa hasil yang diperoleh dari program yang telah terlaksana sudah sesuai dengan kebutuhan masyarakat.

Adanya perubahan pada pola kehidupan keseharian warga sangatlah diharapkan. Hal ini disebabkan karena program yang dilaksanakan berdasarkan kebutuhan. Seperti pengadaan jamban, pada awalnya warga membuang kotoran disungai. Dengan adanya program pengadaan jamban, maka diharapkan kebiasaan buruk tersebut dapat dihilangkan. Kedua ialah renovasi rumah, pada awalnya atap rumah sangat tidak layak untuk dihuni. Namun dengan adanya program renovasi, diharapkan rumah tersebut layak untuk dihuni.

Disisi lain, program pembangunan infrastruktur yang bersifat umum seperti perbaikan saluran air, tentu memberikan dampak yang positif. Adanya perbaikan saluran air, berdampak pada teratasinya per- 
masalahan banjir yang kerap datang tatkala hujan turun. Dan juga adanya program pavingisasi, yang pada awalnya jalan berdebu saat musim panas dan becek saat musim hujan kini tidak lagi. Disamping itu juga, diharapkan adanya pavingisasi memudahkan warga dalam melakukan mobilitas ekonomi. Seperti lalu lintas pedagang kaki lima, lalu lintas drop barang dagangan dari pasar, maupun memudahkan warga dalam berinteraksi dan beraktivitas.

Salah satu fungsi adanya program pembangunan infrastruktur ialah untuk memudahkan mobilisasi warga masyarakat Soekiman, Pribadi, Soemardi, \& Wirahadikusumah (2011). Soekiman, et.al., (2011) mengatakan untuk pembangunan dalam ruang lingkup infrastruktur, dilakukan guna mendukung mobilisasi warga masyarakat untuk memeroleh informasi dan berinteraksi dengan masyarakat luar (Wunas \& Natalia, 2015, p. 170).

Sebagai masyarakat perkotaan yang sekarang hidup di era moderinisasi, perlu kiranya pertukaran informasi dari pihak luar. Salah satu poin penunjang terjadinya tukar informasi ialah dengan perbaikan akses menuju dan keluar daerah. Melalui pembangunan infrastruktur, diharapkan terjadi proses pembangunan dari sektor lainya. Dalam konteks ini ialah pembangunan kualitas individu maupun masyarakat. Dengan demikian pembangunan infrastruktur bersifat resiprokal terhadap sektor lainnya.

Pertukaran informasi tidak harus berada pada pasar seperti yang disampaikan oleh Sunyoto Usman. Menurutnya pertukaran informasi diperoleh pada interaksi masyarakat yang berada pada pusat keramaian seperti pasar. Konsep ini disebut "Strategi Pusat Pertumbuhan. Menurut hemat saya, pertukaran informasi tidak melulu harus terjadi di pusat keramaian seperti pasar. Proses pertukaran informasi juga dapat diperoleh dengan aktivitas mengamati antar warga masyarakat dengan daerah lain (Sutiyono, 2012, p. 23).

Frase "pertukaran informasi" disini tidak harus adanya kontak langsung antara dua pihak. Menurut saya adanya informasi yang dapat diambil dari daerah lain dan adanya informasi yang dapat diambil oleh orang lain dari daerah saya, peristiwa tersebut sudah dapat disebut sebagai pertukaran informasi. Meskipun pertukaran tersebut tidak langusng seperti barter. Dan proses pertukaran informasi yang saya jelaskan tadi dapat diperoleh salah satunya jika akses keluar daerah hunian baik tidak terhalang.

Dari uraian diatas dalam aspek "hasil" dapat diketahui beberapa poin sebagai simpulan. Pertama ialah semua program pembangunan infrastruktur yang telah dilakukan sudah sesuai dengan kebutuhan warga masyarakat. Hal tersebut karena ide program berasal dari usulan dan fakta dilapangan. Baik usulan yang diperoleh dari pertemuan dalam ruang lingkup RT maupun RW.

Kedua, adanya program pembangunan infrastruktur baik yang bersifat individual maupun umum diharapkan dapat memberi dampak yang positif. Dalam konteks ini diharapkan adanya perubahan pola hidup warga miskin menjadi lebih sehat. Selain itu juga dengan adanya program pembangunan infrastruktur yang bersifat umum, diharapkan dapat meningkatkan interaksi serta bertukar informasi dengan daerah lain.

Ketiga, secara umum produk program pembangunan infrastruktur di Kelurahan Procot yang dilakukan oleh BKM Pangudi Mulya terbagi menjadi dua macam. Pertama, ialah program yang bersifat individual seperti: pemasangan jamban, instalasi listrik dan renovasi rumah. Kedua ialah program yang bersifat umum seperti: pavingisasi dan perbaikan saluran air.

\section{SIMPULAN}

Dalam merencanakan suatu program anggota BKM Pangudi Mulya selalu melibatkan partisipasi warga masyarakat nonanggota. Dengan demikian program yang diusung berdasarkan pada kebutuhan dan kepentingan warga masyarakat, terutama warga miskin. Partisipasi warga bisa berbentuk gagasan maupun kebersediaannya menjadi panitia program/KSM.

Pelibatan warga masyarakat nonanggota ke dalam program juga berdasarkan kriteria tertentu. Secara umum warga yang ingin terlibat harus memiliki jiwa sosial, sukarela dan memiliki kompetensi yang cukup. Bentuk partisipasi masyarakat berupa 
ide/gagasan program, konsumsi pada saat pelaksanaan, tenaga baik secara sukarela maupun berperan sebagai tukang sukarela.

Selain itu BKM Pangudi Mulya juga telah memanfaatkan dana yang telah dikucurkan oleh pemerintah baik pusat maupun daerah secara efektif dan efisien. Meskipun demikian, BKM Pangudi Mulya belum mampu memanfaatkan sumber dana lain seperti dana CSR dari perusahaan setempat maupun warga kelas menengah. Sisi lain, dana merupakan unsur penting dalam konteks program pembangungan infrastruktur.

Pada saat pelaksanaan sebagian besar masyarakat bersedia berkontribusi dan berpartisipasi aktif tanpa adanya paksaan adari anggota BKM. Terkait dengan permasalahan yang muncul dilapangan maka anggota BKM Pangudi Mulya dapat mengatasinya dengan baik melalui metode rapat kordinasi antar anggota dan pendekatan persuasive saat berhadapan dengan masyarakat dilapangan. Selain itu juga dengan melibatkan tokoh masyarakat setempat.

Secara umum program yang telah disusun dapat dilaksanakan secara tepat waktu karena adanya partisipasi dari masyarakat non-anggota. Dikarenakan semua program berasal dari aspirasi dan usulan warga masyarakat maka, program-program yang telah disusun sudah sesuai dengan kebutuhan warga masyarakat.

\section{DAFTAR PUSTAKA}

Asnuddin, A. (2012). Pembangunan infrastruktur perdesaan dengan pelibatan masyarakat setempat. Smartek, 7(4), 292-300.

Stufflebeam, D. L. (1994). Empowerment evaluation, objectivist evaluation, and evaluation standards: Where the future of evaluation should not go and where it needs to go. Evaluation Practice, 15(3), 321-338. https://doi.org/10.1016/o8861633(94)90027-2

Stufflebeam, D. L., \& Shinkfield, A. J. (2012). Systematic evaluation: $A$ selfinstructional guide to theory and practice (Vol. 8). Springer Science \& Business Media.
Weiss, D. J., Brennan, K., Thomas, R., Kirlik, A., \& Miller, S. M. (2009). Criteria for performance evaluation. Judgment and Decision Making, 4(2), 164.

Andriany, D. (2015, October). Pengembangan model pendekatan partisipatif dalam memberdayakan masyarakat miskin Kota Medan untuk memperbaiki taraf hidup. In Seminar Nasional Ekonomi Manajemen dan Akuntansi (SNEMA) (pp. 30-39).

Ritzer, G., \& Goodman, D. J. (2004). Teori sosiologi modern. Jakarta: Prenada Media

Suminar, H. A., Hanim, A., \& Wahyu, F. (2016). Pengaruh pembangunan infrastruktur terhadap pendapatan regional Kabupaten Jembe. Artikel Ilmiah Mahasiswa.

Pengesti, I. N. (2012). Implementasi program nasional pemberdayaan masyarakat mandiri perdesaan (PNPM-MP) di Desa Sonowangi Kecamatan Ampelgading Kabupaten Malang. Thesis. Universitas Negeri Malang: Malang.

Razali, I. (2004). Strategi pemberdayaan masyarakat pesisir dan laut. Jurnal Pemberdayaan Komunitas, 3 (2), 61-68.

Ife, J., \& Tesoriero, F. (2008). Community development: Alternatif pengembangan masyarakat di era globalisasi. Yogyakarta: Pustaka Pelajar

Owolabi-Merus, O. (2015). Infrastructure development and economic growth nexus in Nigeria. International Journal of Academic Research in Business and Social Sciences, 5(1), 376.

Sutiyono, S. (2012). Pemberdayaan masyarakat desa dalam pelaksanaan program desa wisata di Daerah Istimewa Yogyakarta. Jurnal Kepatihan

Wunas, S., \& Natalia, V. V. (2015). Pembangunan Infrastruktur Transportasi di Kota Makassar. Jurnal Transportasi, 15(3), 169-178

Suharto, E. (2005). Analisis kebijakan publik: panduan praktis mengkaji masalah dan kebijakan sosial. Bandung: Alfabeta.

Sumodiningrat, G. (1999). Pemberdayaan masyarakat dan jaring pengaman sosial. Gramedia Pustaka Utama. 
JPPM (Jurnal Pendidikan dan Pemberdayaan Masyarakat), 5 (2), 2018 - 121 Fatwa Widodo

Soekiman, A., Pribadi, K. S., Soemardi, B. W., \& Wirahadikusumah, R. D. (2011). Factors relating to labor productivity affecting the project schedule performance in Indonesia. Procedia Engineering, 14, 865-873.

Hermawan, Y., \& Suryono, Y. (2016). Partisipasi masyarakat dalam penyelenggaraan program-program pusat kegiatan belajar masyarakat Ngudi Kapinteran. JPPM (Jurnal Pendidikan dan Pemberdayaan Masyarakat), 3(1), 97-108. doi:https://doi.org/10.21831/jppm.v3i1.811 1

Suryono, Y., \& Tohani, E. (2016). Inovasi pendidikan nonformal. Yogyakarta: Graha Cendekia. 